\title{
空・不空如来蔵について
}

——隋唐時代における『勝鬟経』諸注釈書を中心にして——

\section{楊王 飛}

\section{1. 問題の所在}

仏教における空の概念は初期仏教以来用いられてきたものであるが, 大乗仏教 になると, 特に『般若経』や中観派によって強調され, さらに『勝举経』の如来 蔵思想と結びつき, 空如来蔵と不空如来蔵という概念を創り出した。筆者は以前 に，中国南北朝時代の仏教者たちによる空如来蔵と不空如来蔵に関する解釈を考 察したが ${ }^{1}$, 今回はその続きとして, 隋唐時代の仏教者たちの理解を考察した い. そのため, 本稿は現存する隋唐時代における三本の『勝鬘経』注釈書（浄影

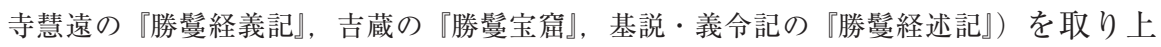
げ，その中の空如来蔵と不空如来蔵に対する解釈を検討するものである.

\section{2. 浄影寺慧遠の『勝鬘経義記』}

まず慧遠は空如来蔵を解釈して,

世尊, 空如来蔵, 総じて以て標挙す。此の義は云何ん，釈に三種有り。一には妄法の中は 空にして真実の如来蔵性無きを空如来蔵と名づく，二には妄法は虚無なり．故に名づけて 空と為す．此の空の義を知って能く如来を成ず．故に空義を名づけて如来蔵と爲す．三に は空の法は如来の真性を能蔵するを空如来蔵と名づく（『勝髲経義記』『新纂続蔵』19, 889a)

という。即ち, 三種の解釈の第一は, 真実の如来蔵性がないので, 空如来蔵とい うのである，第二は，「妄法」は「虚無なるもの」であるので，「空」と名づけ， また，この「空の義」を知るならば「如来」を成就するので,「空の義」を「如 来蔵」と称することができるとしている，第三は，空如来蔵は虚妄の法であり， 「能蔵」という特徵から解釈している。つまり,「空性の法」は「如来真実の性」 を隠覆することができるという側面から解釈している. 続いて, 彼は不空如来蔵 を次のように解釈している. 
不空蔵とは，総じて以て標挙す，恒沙の仏法は，体は有にして無ならず，故に不空と日 う。‥不空蔵を知るを, 云何んが空と名づけん，義は上に釈するが如く，真法は離相及び 離性の故に，通じて名づけて空と為す。(『勝鬟経義記』『新纂続蔵』19,889a)

即ち, 恒沙の仏法が備わっており，欠いていないので,「不空」であるという. さらに，ここでは，「不空」を「離相及離性」としている，従って，慧遠は「相」 「性」の概念を導入して空・不空如来蔵を「空」という概念に統一させた ${ }^{2)}$. 空・不空如来蔵を「空」に統一する解釈は他の注釈書の中では見られないので, 彼独自の解釈であろう.

\section{3. 吉蔵の『勝鬚宝窟』}

吉蔵は「空如来蔵」を解釈する時，大いに慧遠の説を引き継いでいる．例えば,

釈に二種有り。一には妄法の中は空にして真実如来性無きを空如来蔵と名づく．此は是れ 互無空なり，二には妄法は虚恠なるが故に名づけて空と為す。此は当体に空を明す．此の 空義能く如来を蔵するを以ての故に空如来蔵と名づく（『勝髪宝窟』『大正』37,74a)

この部分は明らかに慧遠『義記』の説（『勝賰経義記』『新纂続蔵』19,889a）と一致し ている. 即ち, 吉蔵は慧遠の第一種の解釈を採用した上で,「互無空」としてい る.つまり, 妄法に如来性がなく, 如来性に妄法もない. この解釈の中にはっき り「真」と「妄」を区別している傾向が明らかである。また, 吉蔵の「妄法虚 炋」「能蔵如来」も慧遠の「妄法虚無」・「能蔵如来真性」の変形であろう。続い て, 吉蔵は『涅槃経』の説を引用して, 空如来蔵と不空如来蔵を解釈している.

空如来蔵不空如来蔵は, 即ち是れ如来蔵は中道の義なることを明かす，空蔵は煩悩畢竟空 なることも明かすが故に有と為すべからず，不空蔵は一切の功徳を具するが故に無と為す べからず，非有非無，即ち是れ中道なり。故に『涅槃経』に云く，“仏性とは，是れ三菩 提中道の種子なり”と. 中道種子とは, 此れ隠時を挙げて言と為す. 故に種子と名づく. 中道顕現すれば, 即ち是れ仏なり。故に『涅槃経』に云く, “中道の法, 之を名づけて仏 と為す”と，空・不空の二智を得るは，即ち是れ中道を得るなり．故に『涅槃経』に云く， “中道を得るが故に大法師と名づく”と．(『勝倀宝窟』『大正』37,73c)

即ち, 空・不空如来蔵は「如来蔵 $=$ 中道」という道理を述べていると吉蔵は主張 している，空如来蔵は「煩悩畢竟空である」ことを指し，「非有」を顕わしてい る. 不空如来蔵は「一切の功徳を具備する」ことを指し,「非無」を顕わしてい る。「非有非無」は即ち,「中道」である。以上のことから, 吉蔵は経の空・不空 
如来蔵と『涅槃経』の「仏性は中道種子である」とを同一視していることが分か る. 吉蔵の空・不空如来蔵の解釈が経意に沿っているが，経意に拘らず，三論宗 の立場からそれらを中道に統一している。つまり, 吉蔵が最も表したいものは空 如来蔵と不空如来蔵はただ究極の中道に至るまでの途中概念（方便）に過ぎない.

\section{4. 基説・義令記の『勝䰁経述記』}

基は，唯識の立場から「空」を解釈して，

古来相仏して, 真空を以て如来蔵と為すは，非なり．此は是れ清弁等の宗なり．然るに梵 本に二の名有り．若し若多を名づけて空と為さば，空とは無なり。若し瞬若多を空性と名 づけば, 性とは有なり，今，空と言うは，空より顕わす所の理の故に空と名け，体に拠り て有なり。(『勝髪経述記』『新纂続蔵』19,919b)

という，基はまず中観派の実空をもって如来蔵とする理解が間違っていると述べ ている，それから，「空 (šunnya)」と「空性 (śūnyatā)」とを峻別し，「空 (śūnya)」 は無であるが,「空性（śūnyatā)」は有であるという。『勝䰋経』の「空」が害は空 より顕わしている「空性」であり，「有」であると基は理解している．従って， 「如来蔵」も「無」ではなく, 「有」である。 それでは, 彼は空・不空如来蔵をど のように解釈しているのかを見よう.

如来蔵に四種有り。『楞伽経』に依れば, 二有り。謂く, “阿梨耶識を空如来蔵と名づけ, 無漏薰習を具足するを不空如来蔵と名づくるなり．”此の経に依れば，二有り．謂く，諸煩

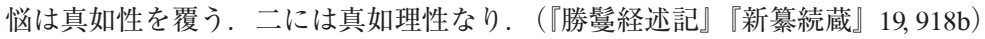

即ち, 基は空・不空如来蔵について, 『入楞伽経』の識説に依れば,「阿梨耶識」 と「具足無漏薰習」との二に分けることができ，『勝髶経』の説に依れば，「諸煩 悩は真如性を隠覆すること」と「真如理性」との二に分けることができると述べ ているが, 実は『勝䯹経』の原意では, 空如来蔵は煩悩を欠いており, 不空如来 蔵は功徳を具備しているのである。 また，基は次のように言う。

釈の中に二有り。初めに空を釈す，二に不空を解す。“世尊空如来蔵”より“一切煩悩”に 至るまでと言うは, 述べて日く, 空を解すなり。四種の如来蔵の中に, 能く真理を覆隠す るを “空如来蔵”と名づく。.... 世尊不空如来蔵”より “不可思議仏法”に至るまでと言う は，述べて曰く，不空を解すなり，此の真理は煩恼に覆われる所と為る，不離脱等は諸の

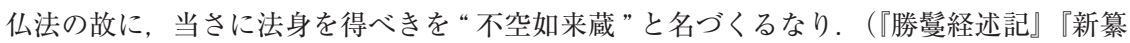
続藏』19,919c) 
即ち, 煩恼は「真理」を隠覆し得ることが空如来蔵であり, 真理は煩悩に隠覆さ れていることが不空如来蔵である. 基の理解では, 空・不空如来蔵の関係は「能 蔵・所蔵」或いは「隠・顕」の関係である。これは煩悩との関係で, 或いは「相 空」の立場で, 空如来蔵と不空如来蔵とを理解している.

\section{5. まとめ}

以上の考察から分かるように, 慧遠は「相」「性」の概念を導入して空如来蔵 と不空如来蔵を「空」という概念に統一させた。 空・不空如来蔵を「空」に統一 する解釈は彼以前の注釈書の中では見られないので, 彼独自の解釈であろう. 吉 蔵は慧遠の説に依りながら, 空如来蔵と不空如来蔵を一つの概念に統一させた が，その概念は「空」ではなく，「中道」である．基は慧遠と吉蔵の解釈に対し て, 唯識の立場から解釈し, 空如来蔵と不空如来蔵を皆「有」としている. 換言 すれば, 慧遠と吉蔵は空を性空と理解し, 基は空を相空と理解している. 魏晋南 北朝時代の『勝䭮経』諸注釈書の解釈 ${ }^{3)}$ をも考慮すれば, 隋唐時代までの中国仏 教思想家たちの空思想に対する理解には「相空」から「性空」へ, そしてまた 「相空」へという発展のルートが想定される.

1) 楊 2017.

2）空と不空の関係について，慧遠はより明確に説明している.「空与不空二皆名蔵，俱 是空故.」(『勝䰋経義記』『新纂続蔵』19,888c).

3）楊 2017, 198.

〈参考文献〉

楊玉飛 2017 「空・不空如来蔵の伝承一一中国南北朝時代における『勝䰋経』諸注釈書を中 心にして—」」印度学仏教学研究』66(1): 195-198.

(本論文は中国国家社会科学基金項目「『勝䯭経』と中国如来蔵思想の展開研究」 (18CZJ002）の成果の一部である)

〈キーワード〉『勝鬟経』, 空, 空如来蔵, 不空如来蔵

（宜春学院宗教文化研究中心講師, 文博) 